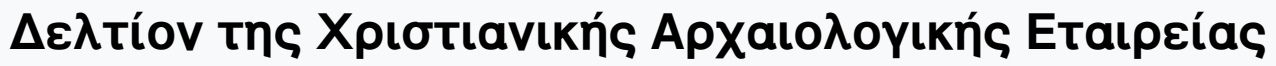

Tó 8 . 8 (1976)

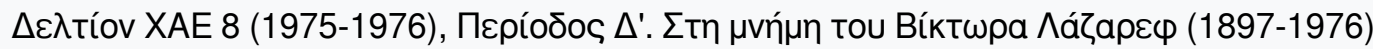

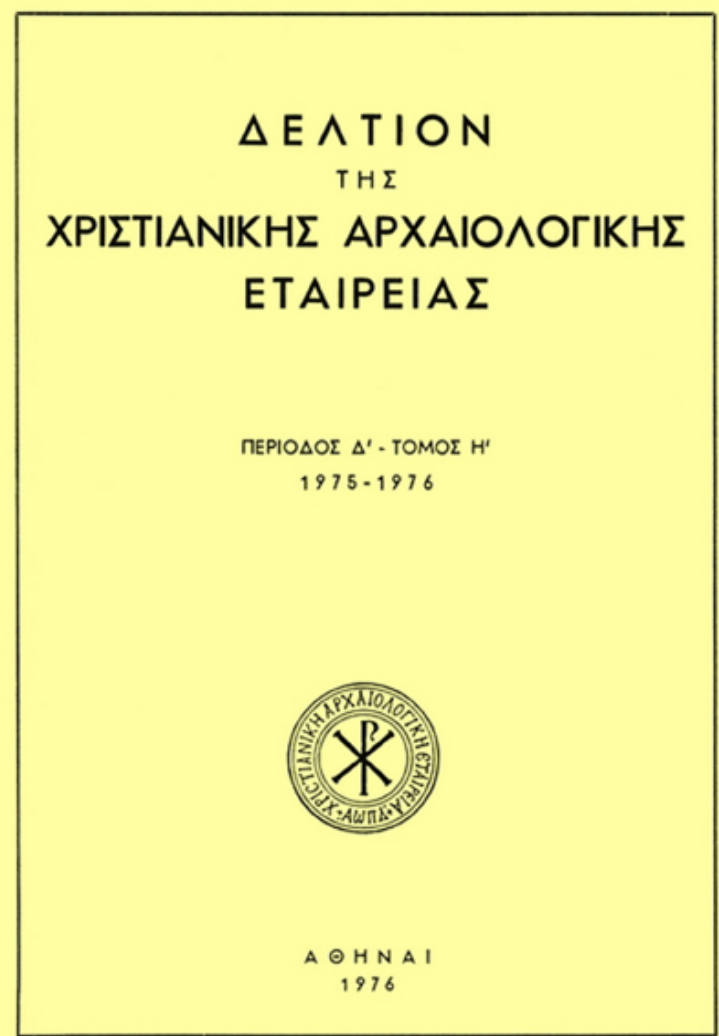

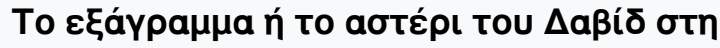

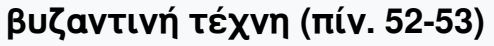

Otto F. A MEINARDUS

doi: $\underline{10.12681 / \text { dchae.851 }}$ 


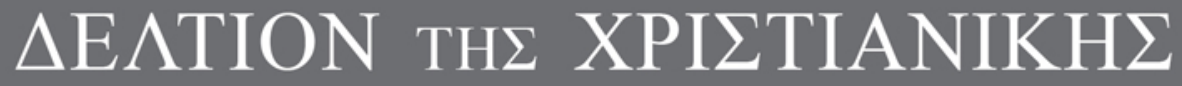 APXAIO $\Lambda$ OГIKH $\Sigma$ ETAIPEIA $\Sigma$}

The Hexagram or the Magen David in Byzantine Art (Tív. 52-53)

Otto MEINARDUS

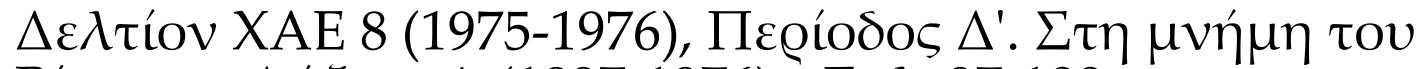

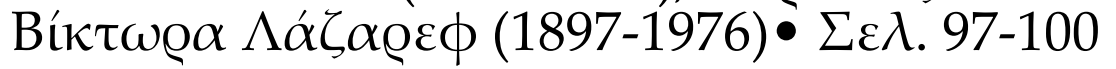

A@HNA 1976 


\title{
THE HEXAGRAM OR THE MAGEN DAVID IN BYZANTINE ART
}

\author{
( PL. $52-53$ )
}

A widespread and common misconception - especially current since the beginning of the 20th century - associates the hexagram or magen David, also known as the Shield of David, with the history, religion and cult of Judaism. In fact, wherever the six - pointed star appears in art and architecture many people relate this symbol either to the House of David or the specifically Jewish heritage within Christendom. This misunderstanding has led to numerous unwarranted conclusions, $e . g$. the assigning of certain architectural or cultic fragments (lintels, impost capitals, lamps, etc.) adorned with the hexagram to synagogues or Jewish cult objects.

The purpose of this essay, therefore, is to demonstrate that the hexagram or the six-pointed star enjoyed a much wider acceptance in the past than its relatively recent use as a national and cultic symbol of Judaism in general and the State of Israel in particular. True, the hexagram had a limited place in the ornamentative art and architecture of the Jews, but it fulfilled also the same function in the art and architectural designs of the Christians as well as in the artistic conceptions of other cultures. In this context it is important to restate that the traditional cultic symbol of Judaism was and still is the menorah or seven branch candle-stick, very often flanked by the shofar and the lulav (Exodus XXV : $31 \mathrm{ff}$.; XXXVII : $17 \mathrm{ff}.)^{1}$.

Within the Jewish tradition the earliest reference to the hexagram belongs to the late period of the Kings (600 B. C.), where it was used on a seal of a certain Joshua ben Assayan ${ }^{2}$. The late Jewish tradition which attributed the origin of the hexagram to the Palestinian rabbi Akiba ben Joseph (50 - 132 A. D.) is mere phantasy. The tradition states that the six - pointed star was the messianic symbol of the liberation of the Jews from Roman oppression during the Bar Cochba revolt. From the 2nd century A. D. onwards we discover the hexagram in at least two Palestinian synagogues of the Graeco Roman period. Probably the best known example is the relief on the frieze

1. W. Wirgi n, The Menorah as a Symbol of Judaism, Israel Exploration Journal XII, 1962, pp. $140 \mathrm{ff}$.

2. Gershom Scholem, Das Davidschild. Geschichte eines Symbols, I udaica (Frankfurt) 1963, pp. $75-118$. Ibid., The Curious History of the Six - pointed Star, Commentary, VIII, 1949, pp. $243-251$. 
of the Synagogue in Capernaum ${ }^{3}$ (pl. 53b). But, as Gershom Scholem ironically pointed out, on the same frieze we discover also next to the hexagram the swastika, and yet nobody would seriously argue that because of the use of this symbol in a synagogue, the swastika would become a Jewish symbol ${ }^{4}$. Nevertheless tourist guides and modern promotional literature continue to relate the Graeco-Roman Jewish relief of the Capernaum hexagram to the Davidic Star of the modern State of Israel.

The other design of the hexagram is found on a lintel of the synagogue at Eshtemoa, nine miles south of Hebron ${ }^{5}$. The two hexagrams, the Caper-

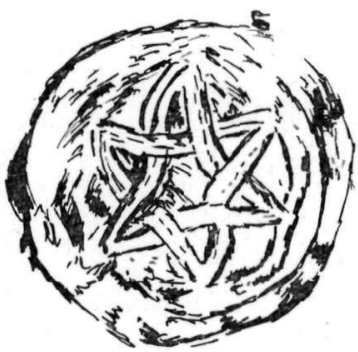

Eshtemoa, Synagogue : lintel. naum star and the Eshtemoa star show distinct peculiarities, and, therefore, we are justified to speak of two types of the six - pointed star, the Capernaum type with its straight interlacing triangles, which eventually became the symbol of the modern State of Israel. On the other hand, the Eshtemoa type with the more or less curved or slightly bent interlacing triangles is most frequently found in the ornamentation of the Byzantine era. So far Capernaum and Eshtemoa are the only early synagogues where the hexagram was

found, and, as stated before, not as a symbol of Judaism but as mere decoration ${ }^{6}$. True, in the case of the Tarentum hexagram, the six-pointed star appears in connection with a Hebrew text beside the name of David, but this isolated case is not sufficient evidence to relate the ancient Jewish cult to this symbol ?

On the other hand, there are numerous illustrations in early and medieval Christian and especially Byzantine art, which show the widespread use of the hexagram as decoration and ornamentation together with rosettes and other geometrical designs, many of which gained in popularity during

3. V. Corbo, St. Loffreda, A. Spijkerman, La Sinagoga di Cafernao, Jerusalem 1970.

4. G. S c h o le m, Judaica, p. 81. The design of the swastika is also found in a recently discovered (1972) mosaic in the synagogue of Ain Gedi.

5. M a y e r and Re if e $\mathrm{nberg}$, The Synagogue of Eshtemoa, Bulletin of the Jewish Palestine Exploration Society IX, 1942, pl. II, 2. Also iđem, Journal of the Palestine Oriental Society, XIX, $1939-41$, pp. $314-326$, pls. xxiii - xxx.

6. Erwin R. Goodenough, Jewish Symbols in the Graeco-Roman Period, New York 1958. Sylvester J. S a 11er, Second Revised Catalogue of the Ancient Synagogues of the Holy Land, Jerusalem 1972.

7. Je a n-Baptiste Frey, Corpus Inscriptionum Judaicarum, Citta del Vaticano, I, 621. 
and after the iconoclastic period. When and why was the six - pointed star adopted in Byzantine art? The eight-pointed star was widely used as an early Christian symbol, for it corresponded to the «mystery of the ogdoad» ${ }^{8}$, and illustrations of its ornamental use are found in many early Christian churches ${ }^{9}$. Examples of the six-pointed star in the decoration of churches are somewhat less common. There is little doubt that in some instances the sixpointed star emerged from the letter combination of the I for Jesus and the $\mathrm{X}$ for Christos, as in the case of the ornamentation of the 5th century Sarigüzel sarcophagus in the Archaeological Museum in Istanbul ${ }^{10}$ or the «Greek Star with six equal branches» in St. Demetrius at Salonica ${ }^{11}$. In later years the six-pointed star clearly signified the heavenly body, as, for example, in the case of the upper part of the Barberini Diptych in the Louvre ${ }^{12}$ or the 10th century Harbaville Triptych in the Louvre ${ }^{13}$.

One of the better known early objects with the hexagram is the 4th century bowl belonging to the Treasure of Mildenhall ${ }^{14}$, while in the Eastern Mediterranean world there exists a considerable collection of Graeco Roman terra - cotta lamps decorated with the hexagram - from Jerash ${ }^{15}$, Samaria ${ }^{16}$, Ephesus ${ }^{17}$, and the Athenian Agora ${ }^{18}$.

The use of the hexagram in Byzantine reliefs is most impressive, and it is this form of ornamentation which has given rise to misunderstandings, especially in the case of fragments. To illustrate the extent of the use of this symbol, we shall list a small selection of some of the better known examples in Byzantine art. There is the hexagram surrounded by an olive - wreath, which belonged to the altar - screen of a church at Khirbet Sufi in the northern

8. Hugo Rahner, Greek Myths and Christian Mysticism, London 1963.

9. Howard Crosby Butler, Early Churches in Syria, Princeton, N. J., 1929 p. 232, published 26 early types of discs with the most frequent Christian designs, none of which include the six - pointed star.

10. D. Talbot Rice, Byzantine Art, Munich 1964, p. 393, fig. 355.

11. A dol phe N. Didro n, Christian Iconography. The History of Christian Art in the Middle Ages, New York 1965, vol. I, p. 393, fig. 102.

12. Ot to Demus, Byzantine Art and the West, London 1970, p. 71.

13. T. R i ce, op. cit. p. 443. Cf. also the famous "Starry Cross» in St. Appollinario in Classe, Ravenna. It is to this cross surrounded with six-pointed stars that the exclamation of the Emperor Heraclius might apply, «O crux splendidior cunctis astris».

14. K. S. Pa inter, Der Schatz von Mildenhall, Die Antike Welt, Zeitschrift für Archäologie und Urgeschichte, VI, 1, 1975, p. 9.

15. E. R. Goode nough, op. cit., I, 161; VII, 358; I, 142; VII, 251.

16. George Andrew Reisner, et. al., Harvard Excavations at Samaria, 1908 - 1910, Cambridge 1924, vol. II, pl. 96 c.

17. Forschungen in Ephesos, Österreichisches Archaeologisches Institut, Wien, Vol. IV, 773, pl. V.

18. Judith Perlzweig, The Athenian Agora. Lamps from the Roman Period. First to the Seventh Century after Christ, Princeton 1961, nos. 353, 2440. 
Negev, now exhibited in the Israeli Museum in Jerusalem ${ }^{19}$. The visitor to the Acropolis in Athens can find at the eastern end of the massive rock an interesting fragment of white Pendelic marble (pl. 52a) with a six-pointed star ${ }^{20}$, an impost block which belonged to one of the Byzantine churches on the Acropolis ${ }^{21}$. In the Basilica of St. John of Ephesus a six-pointed star decorated the marble altar - screen (pl. 52b) together with rosette and cross designs ${ }^{22}$, and a similar theme with the hexagram is also found on the northern section of the altar - screen (pl. 53a) in the 11th century Church of St. Luke of Stiris in Phocis, Greece ${ }^{23}$. Among the ruins of the small three aisled basilica built on top of the bema in the agora of Old Corinth is a 9th century marble fragment with the six-pointed star, probably also part of an altar-screen. A well preserved marble slab, formerly used for an altar screen, was reused in the construction of the 11th century Church of St. Eleutherios (Gorgoepikoos) in Athens, where two six-pointed stars adorn the upper quarters of a wicker cross design ${ }^{24}$.

In all the examples mentioned so far the hexagram had purely decorative purposes, and the origin of the cultic significance of this symbol must be sought in the realm of Jewish magic against demons ${ }^{25}$. Erwin Goodenough has pointed out that the names currently given to the six-pointed star as the «Shield of David» and the five-pointed star as the «Shield of Solomon» are overtranslations, since the Hebrew magen means more generally protection or guard than shield, and simply indicated that the sign brings with it the protection of either David or Solomon. This means that it is a talismanic symbol for the safety of the buildings, objects or persons adorned with it 26 . In the 14th and 15th century the hexagram gained certain cultic and ethnic acceptance in so far as it begins to appear on ofticial Jewish seals. And yet, several hundred years had to pass before this symbol - once a mere decoration used by Jews and Christians alike - became a symbol of national identity in times of persecution and mass death as well as in times of new life for a nation.

OTTO F. A. MEINARDUS

19. Israeli Museum, Jerusalem, Room 204.

20. This fragment is presently (1975) found to the right of the door of the guardhouse below the flagpole of the Acropolis.

21. For Byzantine impost capitals, cf. O. M. Dalto n, Byzantine Art and Archaeology, Oxford 1911, pp. $171-178$.

22. Forschungen in Ephesos, IV, 3, pl. LVII, 3.

23. Gorham Phillips Stevens, The Erechtheum, Cambridge, Mass. 1927 , p. 512, fig. 214.

24. The slab is in the western outer wall in the upper southern section.

25. G. S chole m, Das Davidschild, p. 86 .

26. E. R. Goodenough, op. cit, I, p. 68. 
a . Acropolis, Athens. Marble impost block.

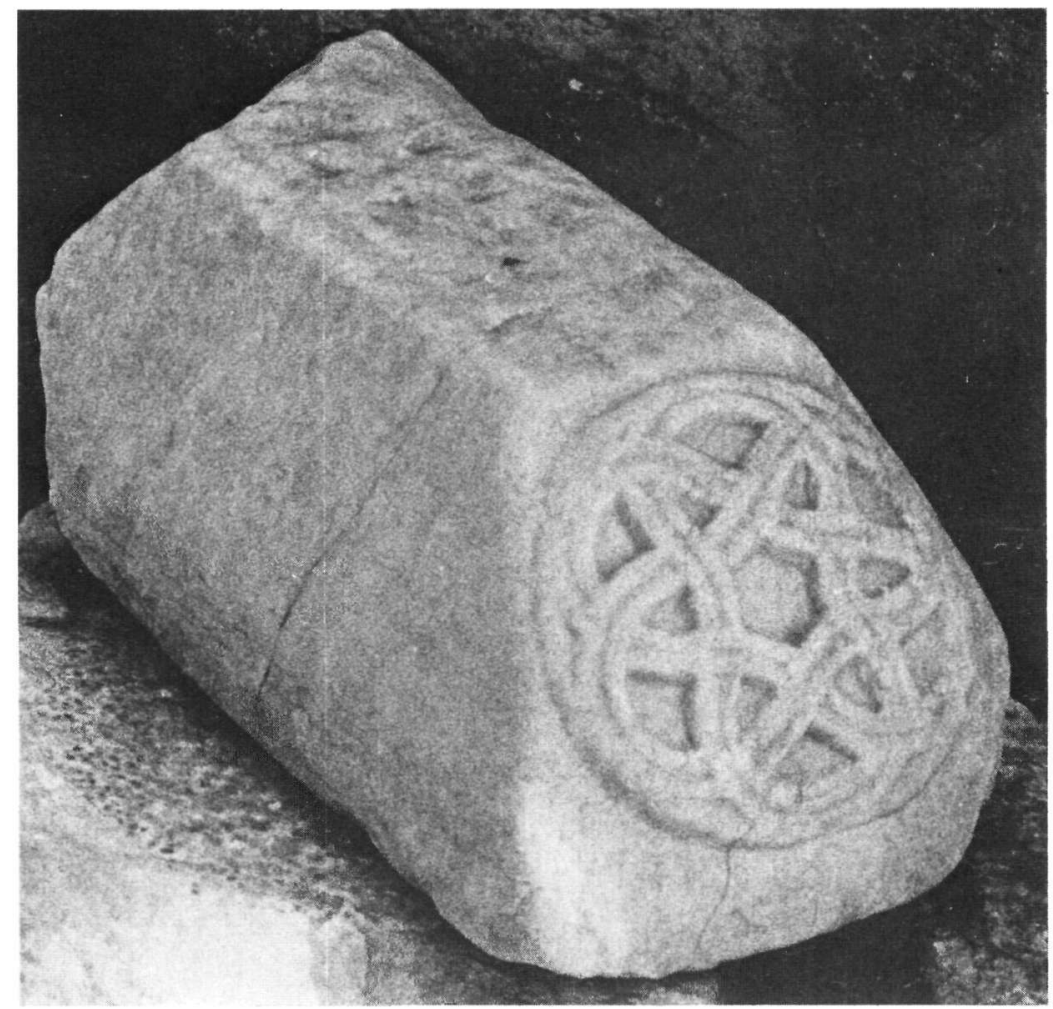

b. Ephesus, church of St. John.

Relief altar - screen.

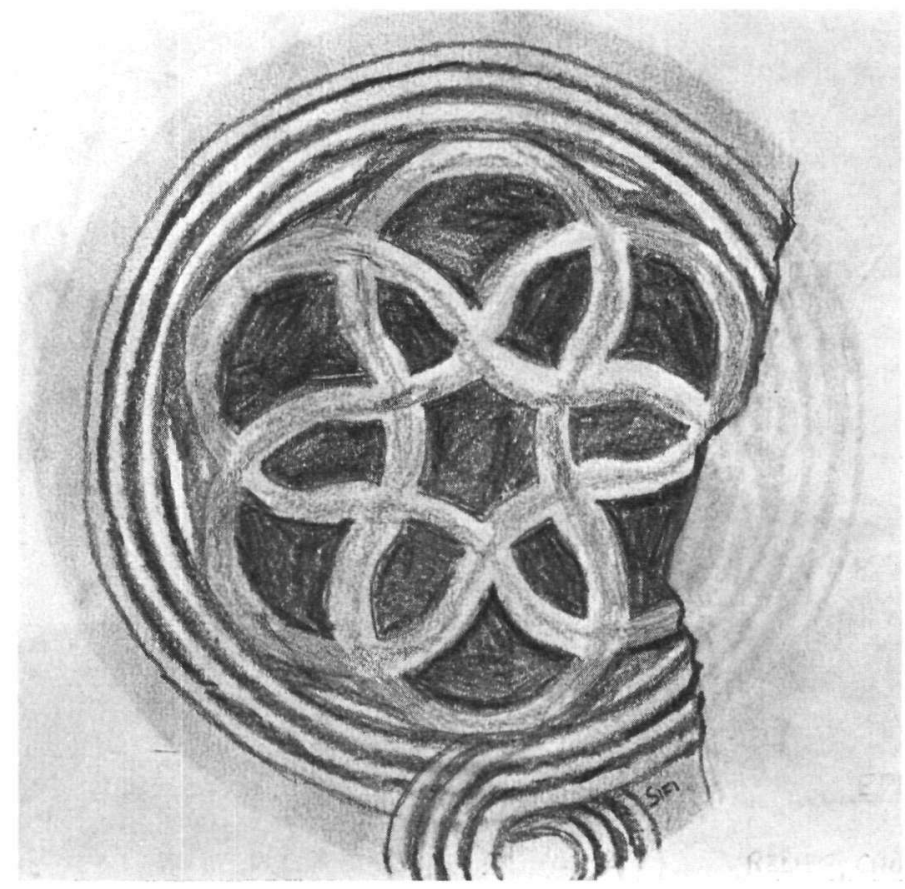



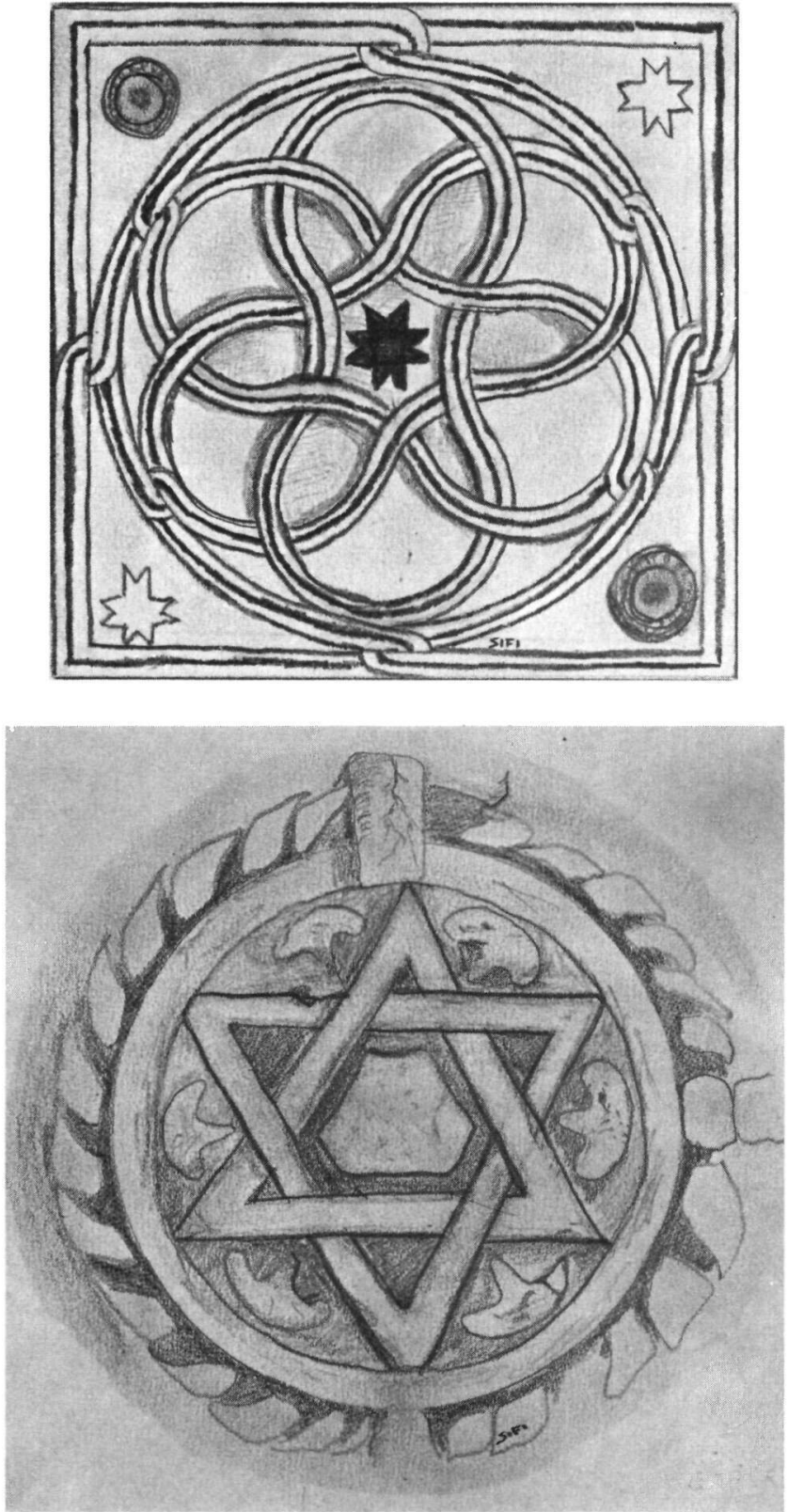

a. Church of St. Luke of Stiris, Phocis. Relief altar - screen.

b. Capernaum, Synagogue. Relief. 